\title{
Effect of concession model and deregulation logistics policy for increasing port customer satisfaction in Indonesia
}

\author{
Sirajuddin $^{1, *}$, Sunaryo $^{2}$, T. Yuri Zagloel ${ }^{1}$ \\ ${ }^{1}$ Department of Industrial Engineering, Indonesia University, 16424 Depok, Indonesia \\ ${ }^{2}$ Department of Mechanical Engineering, Indonesia University, 16424 Depok, Indonesia
}

\begin{abstract}
This paper analyzes the effect of port concession and the deregulation of logistics policy implementation on port customer satisfaction. This research uses 5 latent variables and 18 manifest / indicator variables which are described in the form of Likert scale questionnaires distributed to Port Customers in Indonesia which are freight forwarder, import-export companies and port operators. From SEM structural equations and model measurement results, it can be concluded that the effect of concession and deregulation logistics policy on the overall customer satisfaction is acceptable and data support the model. Port concession variable has positive path coefficient of 0.88 and $t$ statistic of $5.86>1.96$. Infrastructure and Superstructure Variable has positive path coefficient of 0.61 and $t$ statistic of $3.66>1.96$ deregulation logistics policy Variable has positive path coefficient of 0.24 with $t$ statistic of $2.04>1.96$. Integration System Technology Variable has positive path coefficient of 0.21 with $\mathrm{t}$ statistic of $2.39>1.96$ so it can be concluded that the overall hypothesis can be accepted and data supports the model.
\end{abstract}

\section{Introduction}

Indonesia is one of the countries located in Southeast Asia, an archipelago of 17,499 islands flanked by the Pacific Ocean and Indian Ocean as well as the Continent of Asia and the Continent of Australia [1]. As the largest archipelago country in the world, Indonesia has great potential to be the world's maritime axis. The potential of fishery and abundant natural resources become competitive advantage for Indonesia [2]. There are several policies that have been carried out by the government, among others, firstly, the concept of sea toll to reduce price disparity between eastern and western regions through a policy of logistic price subsidy [2]. Secondly, the Port Concession for the improvement of infrastructure and superstructure of the Port [3]; thirdly, deregulation of regulations related to bureaucracy and logistic service procedures standard in the Port that the cost borne by consumers and dwelling time in the Port would be more efficient [4]. To realize the ideals

*Corresponding author: Sirajd_udin@yahoo.com 
of Indonesia into the world's maritime axis, the development of Port infrastructure and superstructure is absolutely necessary to support inter-states, and inter-islands trade. Furthermore, to provide excellent service and quality of service more efficient, the various logistics policies and service procedures in the Port are revised as short as possible so that the service and operational time of the Port is getting shorter and the logistics cost incurred by the consumers become more efficient. The deregulation policy is the regulation of the Ministry of Finance regarding import-export procedures at Port [5]. Therefore, this paper discusses the effect of Port management reforms and the deregulation of Port logistics policy on Port Service Customer satisfaction. This paper is divided into 5 sections, section 1 is introduction, section 2 discusses the literature study, section 3 is about the structural equation modeling method, section 4 is about analysis and discussion, and section 5 is conclusion.

\section{Literature Review}

The institutional of activities organization at the port which has been regulated by Law No. 17 year 2008 has brought a major change in the industrial sector of Indonesia's ports. The crucial thing regulated in Law 17 year 2008 is the separation of the role of operators and regulators at the port level, where previously Pelindo acted as both, the operator and the regulator at the port. But now Pelindo acts only as a port operator and the role of regulator is carried out by a government agency formed by the Port Authority and Port Operator Unit. This port management reform follows the development of port management in the world where there are four common models in Port management; they are service port, tool port, landlord port, and fully private port [6]. In this model, there is a shift in management of Port Management in the world from monopoly to competition model. This is because the competition model has proven effective in improving port performance. In various researches, include the home industry [7], competition on air transport [8], the influence of competition on porting performance [9], competition levels at the port [10], and research related to competitive models can improve the efficiency [11], competition in improving efficiency, productivity and port performance[12].

Vitor Caldeirinha (2017) concluded that government policies influence the port management model, port strategy, and port performance. One of the determinants of ports that can be upgraded to global logistics is the political-economic environment [13]. Therefore the Port logistic deregulation variable becomes important to be included in the model to improve port performance and customer satisfaction. The indicators in Logistic Policy Deregulation consist of 5 indicators; such as, Efficiency of Local Government Administration, Accelerating the Handling of Ship Documents and Physical Inspection at Ports, Integration of Customs Procedures and Logistic Information at Ports, Manifest Documents and the submission of Customs Clearance Notification and Custom Clearance executed prior to the arrival, and Application of Indonesian National Single risk management system (INSRM) [5, 14]. Furthermore, according to Tongzon (2007) and Bojan Manic (2013) the most crucial thing required in port services is Integration System Technology. There are four indicators of the Integration System such as; Licensing Integration through INSW, Inaportnet Integration between Port Operator with INSW, Integration of Indonesian National Single risk management, Business to Business Epayment Integration. One stop information technology and information system through Indonesia National Single Window (INSW) shall accelerate the process of export and import licensing. This system is expected to be integrated with shipping line, port operator, Directorate General of Customs and Excise, banking and trucking so that all document 
management is online based. This online system also applies to order delivery redemption and electronic payment, and truck parking system to avoid queuing on the highway outside ports, auto gate systems, and Inaportnet integration to speed up the flow of documents and goods at the Port. Variables of Consumer satisfaction in this research consists of 3 indicators namely pre Clearance satisfaction, Customs Clearance satisfaction, and Post Clearance satisfaction $[15,16]$. This activity is known as dwelling time is the time required to unload the goods starting from loading and unloading from the ship until the goods released from the Port. Important activities affecting dwelling time are the flow of importexport documents to be prepared which are examined by Customs to obtain either import approval letter (SPIB) until the release order (SPPB). Import container document plays an important role because it relates to the length of time that must be passed by the container while still in the terminal to wait for the process of documents, payment, and customs clearance is completed. Activities of loading and unloading of goods by Port Operator while inspection of import-export documents by Customs [17, 18].

\section{Research Methodology}

\subsection{Conceptual and Hypothesis Models}

Variable in this research consists of 5 latent variables and 18 manifest variable / indicator. The overall indicator manifest variable is obtained through the review and focus group discussion with stakeholders of the Port which can be seen in Figure 1.

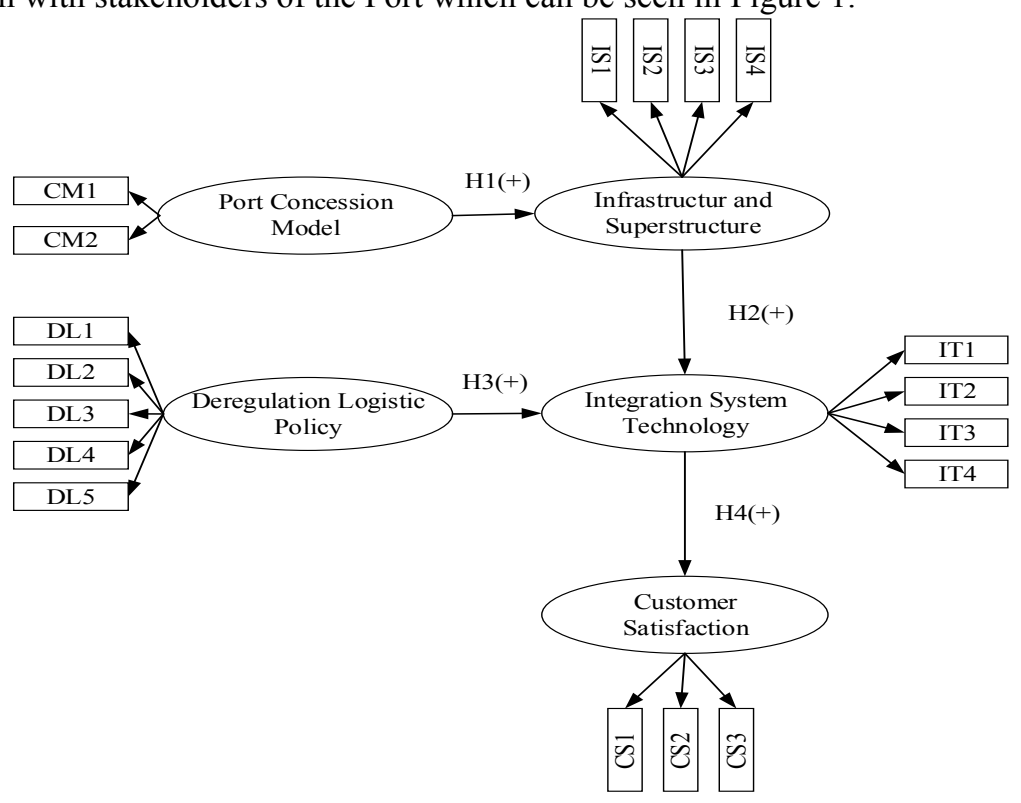

Fig. 1. Research Conceptual Model

The hypotheses of this research are:

1. H1+: There is effect of Port Concession on Infrastructure and Superstructure

2. $\mathrm{H} 2+$ : There is effect of Infrastructure and Superstructure on Integration System Technology 
3. H3+: There is effect of Deregulation Logistic Policy on Integration System Technology

4. H4+: There is effect of Integration System Technology on Customer Satisfaction

\subsection{Data and Sample}

Data processing in this research uses Structural Equation Model (SEM). The data used are primary data obtained through the spread of Likert scale questionnaires 1-5. There are 5 latent variables and 18 manifest variables derived from literature studies through international journals which are then compiled through work group discussions. The respondents of this research are Port user industries that are Freight Forwarder Company, Export-Import Company, and Port Operator. As for the number of questionnaires distributed as much as 350 and the one returned and valid to be processed in SEM is only 258 questionnaires. This number has met 5 to 10 times that of the manifest variable or at least 90 questionnaires required by SEM, so it can be processed to the testing phase of the structural model and the measurement of the Goodness of Fit Model.

\section{Result and Discussion}

\subsection{Structural Model of SEM}

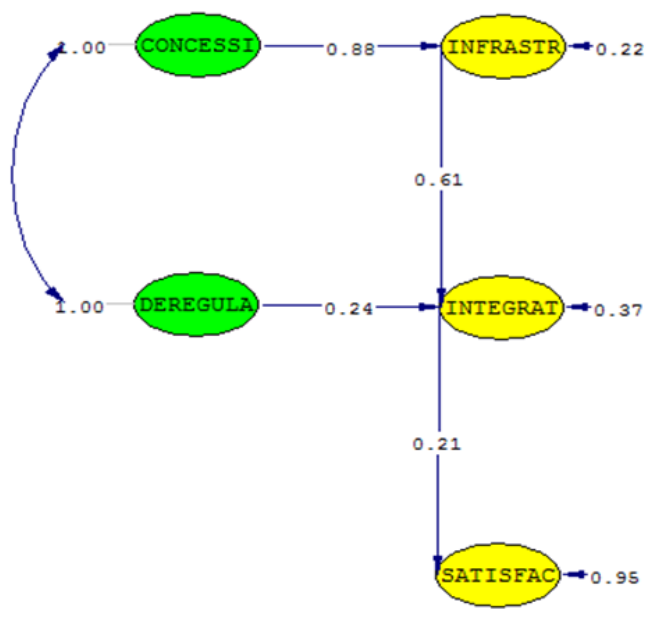

Fig. 2. Structural Model of SEM Standardized Solution

\subsection{Goodness of Fit Indices Model (GOFI)}

To see whether the model is acceptable and the data supports the model, the value of Standardized Loading Factor $(\mathrm{SLF}) \geq 0.5$, Variance Extracted $(\mathrm{VE})>0.5$ and Construct Reliability $(\mathrm{CR})>0.7$. The next step is to test the Goodness of Fit Statistic indicator. In this study the value of the SLF variable manifest $>0.5$ except the value of the indicator of the concession is still poor, but the value of AVE $>0.5$ and $\mathrm{CR}>0.7$ so it can be concluded that the data already shows support the model. Similarly, the results of the calculation of 
Structural Equation modeling shows the level of matching model can be accepted with the value of Normal Theory of Weighted Least Squares Chi-Square $=326.64(\mathrm{P}=0.00)$, but Satorra-Bentler Scaled Chi-Square $=164.52(\mathrm{P}=0.15)>0.05$, Root Mean Square Error of Approximation $($ RMSEA) $=0.022 \leq 0.05$, Comparative Fit Index $(\mathrm{CFI})=1.00 \geq 0.9$, Goodness of Fit Index (GFI) $=0.88 \leq 0.9$ (accepted Fit). Normal Fit Index (NFI) $=0.96 \geq$ 0.9 , Non-Normed Fit Index $(\mathrm{NNFI})=1.0 \geq 0.9$, Incremental Fit Index (IFI) $=1.0 \geq 0.9$ Relative Fit Index $($ RFI $)=0.96 \geq 0.9$, Standardized RMR $=0.062 \leq 0.10$ (accepted Fit), Adjusted Goodness of Fit Index (AGFI) $=0.85 \leq 0.9$ (accepted Fit). The overall value of Goodness of fit indices is Good Fit so it can be concluded that the data supports the model and can be continued on hypothesis testing.

\subsection{Discussion}

In this discussion, there are four hypotheses that have tested the validity, reliability and indicators of Goodness of Fit Indices, including: First, The Port Concession Variable Indicator consists of two which are separations between the operator and the Port regulators (CM1) and the application of Port concessions to both commercial and non-commercial Ports (CM2). From SEM structural equation, it can be seen that there is effect of concession on infrastructure and superstructure with positive coefficient equal to 0.88 and $t$ statistic of $5.86>1.96$ Thus, it can be concluded that hypothesis is acceptable and data supports the model. Port Infrastructure Development can be seen from the various investments made by Port operators particularly the activity of modernization of loading and unloading equipment [11]. The management of ports in Indonesia is still focused on the SOE Port, Pelindo I, Pelindo II, Pelindo III and Pelindo IV, both as port operators obtaining concessions, and also providing Port infrastructure facilities. Furthermore, PT. Pelindo is also still acting as a concession holder such as Port of Tanjung Priok. Thus, in the future this model needs to be reinforced in accordance with the mandate of Law No. 17 year 2008.

Second, the indicator of the latent variables of Infrastructure and Superstructure consists of four indicators: Availability of adequate Port Infrastructure (IS1), Modernization Capacity of Loading and unloading Equipment (IS2), Availability of Warehouse and Stacking Field (IS3), Availability of adequate facilities (IS4). From the SEM structural equation, it can be seen that the effect of Infrastructure and Superstructure on Integration System Technology has a positive coefficient of 0.61 and $t$ statistic $3.66>1.96$ so it can be concluded that the hypothesis is accepted and the data support the model. The factor of significance of the effect of Infrastructure and Superstructure from the perspective of freight forwarders and port operators is the ability of modernization of tools from Port operators. However, this activity is still not maximal; there are still loading and unloading equipment's that have low productivity that it is unable to achieve the operational performance of loading and unloading targets. Similarly, temporary shelter conditions are limited, so that on national holidays congestion and container queue in the Port is still occurred.

Third, Deregulation variables consist of 4 indicators, they are Efficiency Administration Government (DL), Accelerating the Handling of Ship Documents and Physical Examination (DL2), Integration of Customs Procedures and Logistics Information at Port (DL3), Manifest Documents made prior to the arrival (DL4). The deregulation variable indirectly affects Customer Satisfaction. This variable is an independent variable of the Integration System Technology variables that will be associated with Customer Satisfaction variable. The deregulation effect on Integration System Technology can be seen from the result of calculation of Structural equation modeling where the coefficient of deregulation is positive equal to 0.24 with $t$ statistic of $2.04>1.96$ so it can be concluded that $\mathrm{H} 1$ 
hypothesis is accepted and strategy of logistic policy deregulation significantly affects the Integration System Technology. This result is in accordance with Chi-Lok \& Zhang (2009) and Vítor Caldeirinha (2013) studies which state that deregulation logistic policy is an important factor in improving port performance.

Fourth, Integration System Technology Variable consists of 4 indicators; they are Licensing Integration through INSW (IT1), Inaportnet Integration between Port Operator with INSW (IT2), Integration of Indonesian National Single risk management (IT3), Business to Business E-payment integration (IT4). The effect of Integration System Technology on customer satisfaction can be seen from the calculation of Structural equation modeling where the coefficient of Integration System Technology is positive at 0.21 with t statistic of $2.39>1.96$ thus, it can be concluded that the hypothesis is accepted, which means that the effect of Integration System Technology on customer satisfaction is significant. The effect of this INSW implementation can be seen directly from the Port Dwelling time performance in Tanjung Priok where prior to the application of Port concession and deregulation logistic policy, dwelling time in the Port reaches 5-6 days and after concession and deregulation implementation, and INSW is done then dwelling time in 2017 drops to 3-4 days.

\section{Conclusions}

From SEM structural equation and model measurement result, it can be concluded that the effect of concession and deregulation logistics policy model to the overall customer satisfaction is acceptable and data support the model. The results of each research hypothesis testing can be summarized as follows;

1. Port concession variables have a positive path coefficient of 0.88 and $t$ statistics of 5.86 $>1.96$. Therefore, it can be concluded that the hypothesis can be accepted and the data support a significant model, which means that in the confidence interval $95 \%$ there is a significant effect of the Concession variable on Infrastructure and Superstructure.

2. Infrastructure and Superstructure Variable have positive path coefficient of 0.61 and $t$ statistic of $3.66>1.96$ that it can be concluded the hypothesis is accepted and the data support the model which means that in $95 \%$ confidence interval there is effect of Infrastructure and Superstructure on Integration System Technology

3. Deregulation logistic policy variable has a positive path coefficient of 0.24 with $t$ statistic of $2.04>1.96$, therefore it can be concluded that the hypothesis $\mathrm{H} 1$ is accepted and the data support a model which means that in the confidence interval of $95 \%$ there is effect of deregulation logistics policy on Integration System Technology

4. Integration System Technology Variable has a positive path coefficient of 0.21 with $t$ statistic of $2.39>1.96$, thus it can be concluded that the hypothesis is accepted and the data support the model which means that in confidence interval of $95 \%$ there is effect of Integration System Technology on customer satisfaction.

The authors are grateful to the Grand PITTA in University of Indonesia on the funding provided and we also thank the reviewers for their valuable comments and suggestions in this paper.

\section{References}

1. Pelindo, Annual Report Pelindo 2 Year 2016. (2016)

2. Bappenas and Kemenhub, Tol Laut Concept and Implementation 2015 - 2019. (2015) 
3. Kemenhub, Standar Kinerja Operasional Pelabuhan pada 16 Unit Penyelenggaran Pelabuhan. (2013)

4. Kemenhub, Regulation of the Government of the Republic of Indonesia Number 64 Year 2015 on Amendment to Government Regulation Number 61 Year 2009 about Port. (2015)

5. Customs, Customs Clerance and Joint Gate TPS in Tanjung Priok Port (2015)

6. Kemenhub, Rule of The Republic of Indonesia Number 17 Year 2008 about Shipping. (2008)

7. World Bank, Port Reform Toolkit Second Edition (2007)

8. Julien Forder*, S.A., The impact of competition on quality and prices in the English care homes market. Journal of Health Economics 73-83 (2014)

9. N. Adler, and V. Liebert. Transportation Research Part A 64 (2014)

10. Álvarez-SanJaime, Ó., et al., Transportation Research Part B: Methodological 80 (2015)

11. L. W. D. Langen and A. A. Pallis (2013)

12. F. Peter, Wanke and C. P. Barros. Socio-Economic Planning Sciences (2015)

13. A. Masahito. The Research Institute of Economy, Trade and Industry (2013)

14. Yang, Y.-C and S. L. Chen. Transport Policy 45 (2016)

15. D. Yang, A. T. H. Chin and S. Chen. Maritime Policy \& Management 41 (2013)

16. S. Adam. A thesis submitted in partial fulfilment of the requirements for the Degree of Master of Applied Science (Transport Studies) Lincoln University (2009)

17. D. A. Lasse. PT Raja Grafindo Persada Jakarta (2011)

18. A. Artakusuma. Analisis Import Container Dwelling Time Di Pelabuhan Peti Kemas Jakarta International Container Terminal (JICT) Tanjung Priok (2013) 